\title{
PSICHIKOS SVEIKATOS SLAUGYTOJŲ IR SERGANČIŲJŲ ŠIZOFRENIJA ARTIMŲJŲ BENDRADARBIAVIMAS: KOKYBINIS TYRIMAS
}

\author{
Augustė Grinkevičiūtė, Agnẻ Jakavonytė-Akstinienė \\ Vilniaus kolegijos Sveikatos priežiūros fakulteto Slaugos katedra
}

\begin{abstract}
Raktažodžiai: slaugytojai, šizofrenija, artimieji, bendradarbiavimas.

Santrauka

Šizofrenija serga daugiau nei 20 milijonu pasaulio gyventojų. Daugelis asmenų, kuriems diagnozuota šizofrenija, gyvena arba palaiko artimus ryšius su savo šeimos nariais, pavyzdžiui, tevvais, broliais, seserimis ar vaikais. Dažnai sergančiuosius prižiūrintys šeimos nariai pakliūva i situacijas, kuriose pasireiškia sergančiojo agresija ir savęs žalojimas. Tyrimo tikslas - išanalizuoti psichikos sveikatos slaugytojo ir sergančiųjų šizofrenija artimųjų bendradarbiavimą. Tyrime dalyvavo 4 artimieji, vyresni nei 18 metų, kurių šeimose yra šizofrenija sergantis asmuo ir 4 psichikos sveikatos slaugytojai. Taikytas interviu metodas. Tyrimo rezultatai. Šizofrenija sergančiujų artimieji patiria neigiamą aplinkinių požiūrị, turi bendravimo problemų su sveikatos priežiūros specialistais ir su šizofrenija sergančiu šeimos nariu. Psichikos sveikatos slaugytojai šizofrenija sergančiujų artimiesiems konsultacijų metu dažniausiai rekomenduoja rūpintis savo emocine sveikata, stebėti, kad sergantysis tinkamai vartotu jam paskirtus vaistus, moko bendrauti su sergančiuoju, pablogejjus jo sveikatos būklei.
\end{abstract}

\section{Ivadas}

Šizofrenija - tai lètinè psichikos liga, pasireiškianti mąstymo, suvokimo, valios ir emocijų sutrikimais [1]. Šia liga serga daugiau nei 20 milijonų pasaulio gyventojų, o JAV šizofrenija diagnozuota maždaug 3,5 milijono žmonių [2-3]. Lietuvoje pastaraisiais metais šizofrenija sergančių asmenų skaičius (ligotumas) kito nežymiai: 2010 metais šizofrenija sirgo 11670 asmenų, 2011 metais - 11979, 2012 metais 12123, 2013 metais - 12269, 2014 metais - 12162, 2015 metais - 11992, 2016 metais - 12234, 2017 metais - 12031, o 2018 metais - 12103 [4]. Šizofrenija dažniausiai suserga 15-25 metų vyrai ir 23-35 metų moterys [5]. Sergamumas šia liga panašus tarp abiejų lyčių [6]. Šizofrenija sergantys asmenys labai dažnai patiria stigmatizaciją ir diskriminaciją [7]. Liga paveikia visą artimiausią sergančiojo aplinką, tad šeimos narių stigmatizacija taip pat labai plačiai paplitusi [8]. Atlikto tyrimo Kanadoje rezultatai atskleidè, kad net 50 proc. artimujų slepia nuo draugų ar kolegų, kad artimoje aplinkoje yra sergantysis šizofrenija [1]. Kito tyrimo rezultatai atskleide, kad net šiek tiek daugiau nei keturi penktadaliai (83 proc.) šeimos narių, besirūpinančių šizofrenija sergančiu artimuoju, yra patyrę stigmatizaciją dèl artimojo bent vieną kartą [9]. Daugiau nei 1,5 milijono žmonių rūpinasi šizofrenija sergančiais artimaisiais. Beveik pusė (55 proc.) nurodè, kad dèl rūpinimosi šia liga sergančiu artimuoju, jų sveikata ir socialinis gyvenimas buvo stipriai paveikti [10]. Nepriklausomai nuo to, ar sergantysis šizofrenija gyvena su šeima ar ne, šeimoms reikia pagalbos, patarimų, kaip valdyti situaciją, todèl viena iš daugelio psichikos sveikatos slaugytojo pareigų yra šeimos narių, besirūpinančių šizofrenija sergančiu artimuoju, bendradarbiavimas su sveikatos priežiūros specialistais [1].

Darbo tikslas - išanalizuoti psichikos sveikatos slaugytojo ir sergančiųjų šizofrenija artimujų bendradarbiavimą.

\section{Tyrimo medžiaga ir metodai}

Tyrimas buvo vykdomas vienoje Lietuvos ligoninejje, 2019 metų rugsèjo-spalio mėnesiais. Tyrimui atlikti pasirinktas interviu metodas. Tyrime dalyvavo 8 asmenys: 4 artimieji, kurių šeimose yra sergantis šizofrenija ir 4 psichikos sveikatos slaugytojai. Visos tyrimo dalyvès buvo moterys. Interviu metu buvo pateikti 7 klausimai šizofrenija sergančiujų artimiesiems ir 4-psichikos sveikatos slaugytojoms. Su visomis tyrimo dalyvemis buvo susitarta individualiai dèl tinkamo interviu laiko ir dienos. Pokalbis vyko individualiai su kiekvienu asmeniu ramioje aplinkoje, nesant patalpoje kitų žmonių. Visi pokalbiai su tyrimo dalyvemis buvo įrašyti i diktofoną. Surinkti duomenys buvo transkribuojami ir analizuojami turinio analizès metodu. Siekiant užtikrinti duomenų konfidencialumą, tyrimo dalyvèms buvo suteikti kodai: S1 - pirma slaugytoja, S2 - antra slaugytoja, S3 - tre- 
čia slaugytoja, S4 - ketvirta slaugytoja, o sergančiujų šizofrenija artimiesiems kodai suteikti pagal giminystès ryši - mama ${ }_{1}$, mama ${ }_{2}$, sesuo, žmona.

\section{Tyrimo rezultatai ir jų aptarimas}

Dauguma respondenčių nurodè, kad rūpindamosi šizofrenija sergančiu artimuoju, patyrè neigiamą aplinkinių požiūrị, kuris pasireiškẻ kaltinimu, smerkimu, įžeidžiais komentarais (1 lentelè).

Šizofrenija sergančiojo žmona apibūdino savo patirtį: ,....Mano brolis kažkada yra pasakęs man, kad mesk tu ta vyra, ligonis jis yra, tik bereikalingu problemu prisidarai (...) Man gaila savo vyro, širdis niekada neleistu palikti žmogu viena bèdoje....". Tyrimo dalyvė pabrèžè, kad ir giminaičiai smerkia šeimos narius dèl jų artimojo ligos. Sergančiojo sesuo apibūdino labai panašią situaciją: ,...O net ir tolimesni giminaičiai nesupranta, kaip galima prižiūrèti toki žmogu, kažkada man tiesiai i akis pasake, kad dèk i globos namus ir viskas...". Respondentė nurode girdejusi, kaip kiti žmonès izžeidinejo jos sergantị brolị. Galima daryti prielaidą, kad aplinkiniai neigiamai vertina ir smerkia tai, kad artimieji patys prižiūri šizofrenija sergantị šeimos narị. Mama ${ }_{2}$ nurodè, kad kiti asmenys kaltina visus šeimos narius dèl to, kad jų sergantis artimasis kelia įvairių problemų: ,...dažniausiai kaltina mus, kad nemokame prižiürèt tokio ligonio, nes problemu pridaro ir panašiai...". Visos trys tyrimo dalyvės dèl patiriamo neigiamo aplinkinių žmonių požiūrio jautėsi ịskaudintos ir labai išgyveno dèl artimojo ligos. Galima daryti prielaidą, kad aplinkiniu kaltinimas, smerkimas bei ịžeidūs komentarai lemia šizofrenija sergančių artimųjų blogą emocinę būklę, sukelia kančias.

1 lentelè. Respondenčių patirto neigiamo aplinkinių požiūrio dažnis

\begin{tabular}{|c|c|c|c|}
\hline Kategorija & $\begin{array}{l}\text { Subkate- } \\
\text { gorijos }\end{array}$ & $\begin{array}{l}\text { Teiginių } \\
\text { skaičius }\end{array}$ & Teiginiai \\
\hline $\begin{array}{l}\text { Patiriamas } \\
\text { neigiamas po- } \\
\text { žiūris iš aplin- } \\
\text { kinių asmenų }\end{array}$ & \begin{tabular}{|l} 
Kaltina \\
Smerkia \\
Sako ịžei- \\
džius ko- \\
mentarus
\end{tabular} & 3 & 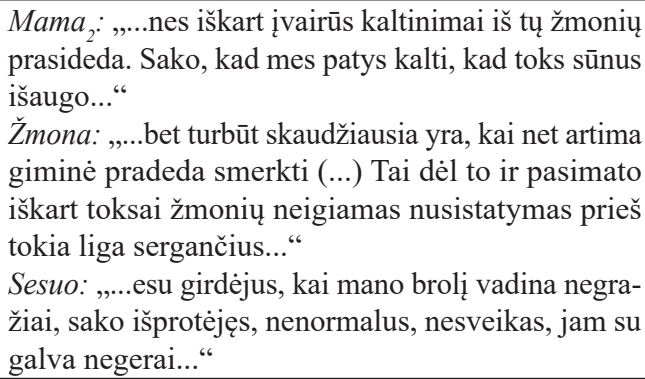 \\
\hline
\end{tabular}

2 lentelè. Respondenčių patirtų bendravimo sunkumų su šizofrenija sergančiu šeimos nariu dažnis

\begin{tabular}{|c|c|c|c|}
\hline Kategorija & $\begin{array}{l}\text { Subkatego- } \\
\text { rijos }\end{array}$ & $\begin{array}{l}\text { Teiginių } \\
\text { skaičius }\end{array}$ & Teiginiai \\
\hline $\begin{array}{l}\text { Sunkumai } \\
\text { bendraujant } \\
\text { su sergančiu } \\
\text { artimuoju }\end{array}$ & $\begin{array}{l}\text { Sunku } \\
\text { susikalbėti } \\
\text { Sunku ịkalbėti } \\
\text { gerti vaistus } \\
\text { Sunku } \\
\text { suprasti, ką } \\
\text { ligonis nori } \\
\text { pasakyti }\end{array}$ & 4 & 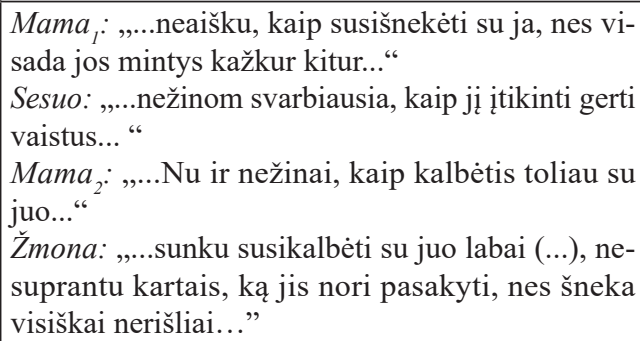 \\
\hline
\end{tabular}

Tyrimo metu buvo siekiama išsiaiškinti problemas, kurias patiria šizofrenija sergančių pacientų artimieji. Tyrimo dalyvès nurodé, kad labai sunku bendrauti su šizofrenija sergančiu šeimos nariu (2 lentelè).

Visos 4 respondentès nurodè, kad patiria sunkumų, bendraudamos su šizofrenija sergančiu šeimos nariu. Šizofrenija sergančiojo sesuo sakè, kad: ,....kol jisai sveikas, tai viskas gerai, bet vos tik nustoja gerti vaistus, tiesiog pats nusprendžia, kad aš negersiu vaistu daugiau, man nereikia ir t.t. ir tada jau prasideda nesamonés, užeina jam, jo niekad nepagausi, visada bègs nио mūsu....". Galima vertinti, kad problemos atsiranda tada, kai sergantysis pats nusprendžia daugiau nevartoti jam paskirtu vaistų. Sesuo nežinojo, kaip ịtikinti artimaji vartoti vaistus. Mama teigè: ,...Aišku, viskas prasideda, kai vaistu nebegeria, bandai ịkalbinèti, kaip nors slapčia įduoti, bet vis tiek nesužiūri visada, o po to tik randi pilna neišgertu tablečių, tai tada pasidaro aišku, kodèl vèl pablogejo, nu ir neklauso niekad manęs...". Mama, sakè, kad ji deda labai daug pastangų, kad sūnus visus vaistus vartotų reguliariai, tačiau „...ateina kartais toks laikas, kai negeria pats savo noru ju...". A. Svettini ir kt. (2015) nustatè, kad daugiau nei trečdalis (38 proc.) globėjų kasdien ginčijasi, bandydami savo šeimos nari ịtikinti, kad vartotų vaistus, o 50 proc. respondentų nurodè, kad nuolatinis stebejjimas, ar jų sergantis šeimos narys išgèrè visus vaistus, yra didelè našta [12]. Šizofrenija sergančiojo žmona išreiškè baimę dèl nežinojimo, kaip elgtis, pablogèjus artimojo būklei: ,...šita liga labai baisi, nesuprasi, ka jis mato, girdi ar jaučia, kai jam visai blogai pasidaro...". Mama taip pat rodo su- 
sirūpinimą dukra, kai pablogèja jos būklè: „,...Kai psichozé užeina, tai išvis baisu būna, nesamones kalba, nesusikalbam visai abi, atrodo taip gaila jos, bet ir tuo pačiu neramu, nes nežinai, ka ji tuo metu galvoja, ka gali padaryti...". Galima daryti prielaidą, kad respondentès jaučia baimę, nes nežino, kaip tinkamai kalbètis su psichozę išgyvenančiu artimuoju.

Šizofrenija sergančiojo žmona nurodė bendravimo su sveikatos priežiūros specialistais problemą. Pasak tyrimo dalyvès, ,...su jais sunku pasikalbèti labai, visada labai užimti, o dar kai kurie net būna paleidžia jị visiškai nepasveikusị i namus ir sako, kad jis turi būti visada toks. Nu, aš esu jo žmona ir tikrai žinau, koks jis būna, kai jam yra viskas gerai, tai ir kyla konfliktai su jais po to...". Galima teigti, kad galbūt ne visuomet sveikatos priežiūros specialistai įžvelgia sergančių šizofrenija artimujų lūkesčius. Respondentė pabrèžè, kad trūksta bendradarbiavimo su jais: ,...klausiam, bet taip ir neisivaizduojam, ka jam ten daro, kaip gydo ir panašiai, norètųsi kartais ir pasitarti su jais...".

Tyrimo metu siekta išsiaiškinti, kokias rekomendacijas psichikos sveikatos slaugytojos teikia sergančiujjų artimiesiems. Šis klausimas buvo užduotas ir artimiesiems, ir slaugytojoms. Dvi respondentès $\left(\mathrm{mama}_{1}\right.$ ir mama $)$ teigè, kad nèra gavusios slaugytojų rekomendacijų.

Daugiau nei pusė respondenčių nurodè, kad viena iš slaugytojų rekomendaciju - stebèti, jog šizofrenija sergantis šeimos narys tinkamai vartotu jam paskirtus vaistus (3 lentelè).

Šizofrenija sergančiojo sesuo interviu metu sakè, kad ,...svarbiausia yra laiku pastebèti, kada pasikeičia brolio elgesys. Tai reiškia, kad jis negeria vaistu...". Ga- lima daryti prielaidą, kad sergančiojo elgesys gali parodyti, ar jis vartoja vaistus, ar ne, todèl labai svarbu laiku pastebėti elgesio pokyčius. Respondente pažymejjo, kad stebejjimas nepadeda išvengti artimojo ligos remisijos, todèl jai būtų geriau žinoti, kaip įkalbèti artimajị vartoti vaistus. Keletas $(n=3)$ respondenčių nurodė, kad slaugytojai teikia artimiesiems informaciją apie šizofreniją. Šizofrenija sergančiojo sesuo pasakè, kad slaugytoja, aiškindama apie ligą, patarė pasinaudoti vaizdinėmis priemonėmis: „...net viena patarè pažiūrèti filma kažkokị apie sergančius šizofrenija, tik pavadinimo dabar neprisimenu, bet kai aš ji pažiürèjau, padèjo lengviau suprasti, ka tie sergantys šia liga patiria...“. Slaugytoja $\mathrm{S}_{2}$, aiškindama apie ligos simptomus, patarè artimiesiems kuo greičiau kreiptis ị sveikatos priežiūros įstaigą, pastebejjus sergančiojo šizofrenija elgesio pokyčius. Slaugytoja $\mathrm{S}_{4}$ sakè, kad internete esanti informacija yra naudinga: ,....bet dažniausiai jeigu jie nori ka nors sužinoti, pasakau, kad pasiskaitytu internete. Ten yra tikrai labai daug informacijos apie šita liga, daug forumu visokiu, todèl manau naudingiau, nei pasakojant...". S. Sabanciogullari ir H. Tel (2015) atliktame tyrime šeimos nariai nurodè, kad dažniausiai prašo paaiškinti apie vaistų vartojimą ir bendravimą su šizofrenija sergančiais šeimos nariais bei jų pykčio valdymą, o informacijos poreikis apie pačią ligą ar jos simptomus buvo mažas [13]. Mūsų tyrime paaiškejjo, kad slaugytojai moko šizofrenija sergančiųu artimuosius bendrauti, pablogèjus sergančiojo būklei (4 lentelè).

Sergančiojo sesuo ir žmona pabrèžè, kad slaugytojai rekomenduoja ramiai kalbėtis su haliucinacijas, psichozę patiriančiu šeimos nariu, jam neprieštarauti ir nesityčioti iš jo. Slaugytoja $S_{2}$ pritare šioms respondentems, nurodydama, kad artimiesiems labai svarbu saugoti save ir, esant agresyviam šeimos nario elgesiui, neprieštarauti.

3 lentelè. Slaugytojų rekomendacijos stebèti paskirtų vaistų vartojimą, dažnis

\begin{tabular}{|c|c|c|c|}
\hline Kategorija & $\begin{array}{c}\text { Subkate- } \\
\text { gorijos }\end{array}$ & $\begin{array}{l}\text { Teiginių } \\
\text { skaičius }\end{array}$ & Teiginiai \\
\hline $\begin{array}{l}\text { Stebėti, kad } \\
\text { šizofrenija } \\
\text { sergantis } \\
\text { šeimos } \\
\text { narys } \\
\text { tinkamai } \\
\text { vartotu jam } \\
\text { paskirtus } \\
\text { vaistus }\end{array}$ & $\begin{array}{l}\text { Vaistų varto- } \\
\text { jimo regulia- } \\
\text { rumas }\end{array}$ & 5 & 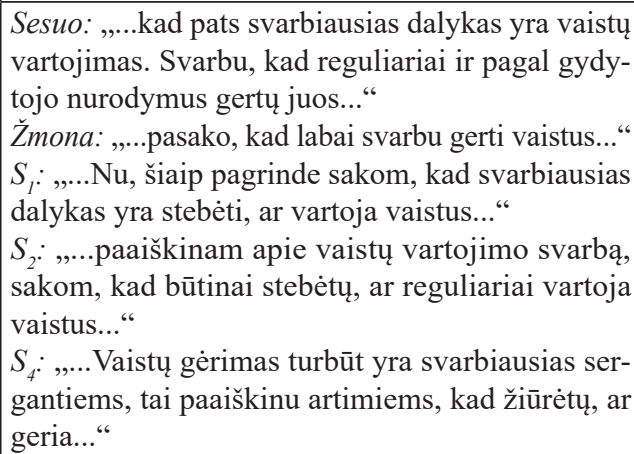 \\
\hline
\end{tabular}

4 lentelè. Artimųjų mokymo bendrauti su sergančiuoju, pablogèjus jo būklei, dažnis

\begin{tabular}{|c|c|c|c|}
\hline Kategorija & $\begin{array}{l}\text { Subkate- } \\
\text { gorijos }\end{array}$ & $\begin{array}{l}\text { Teiginiu } \\
\text { skaičius }\end{array}$ & Teiginiai \\
\hline $\begin{array}{l}\text { Mokymas } \\
\text { bendrauti } \\
\text { su sergan- } \\
\text { čiu šizofre- } \\
\text { nija šeimos } \\
\text { nariu, } \\
\text { pablogèjus } \\
\text { jo būklei }\end{array}$ & $\begin{array}{l}\text { Rekomenduoja } \\
\text { ramiai kalbėtis } \\
\text { su artimuoju }\end{array}$ & 3 & $\begin{array}{l}\text { Sesuo: ,...Pasakė, kaip bendrauti, kai jis haliuci- } \\
\text { nacijas visokias patiria, kad geriau reikia neprieš- } \\
\text { tarauti, ramiai kalbètis..." } \\
\text { Žmona: ,...Mokina, kaip elgtis su žmogum psi- } \\
\text { chozės metu, kad jokiu būdu nesityčioti iš jo, ge- } \\
\text { riau ramiai pasiklausyti, ką kalba, nesipriešinti ir } \\
\text { panašiai...“ } \\
S_{2}: \text {,...Pamokinu juos kaip elgtis, kai pablogèja } \\
\text { būklè, haliucinacijos ar agresyvus būna, kad jam } \\
\text { nesipriešintų, neprieštarautų, kad save saugotų...“ }\end{array}$ \\
\hline
\end{tabular}


Tyrimo dalyvės išskyre dar vieną slaugytojų rekomendaciją artimiesiems - rūpintis savo emocine sveikata. Slaugytoja $\mathrm{S}_{1}$ nurodè, kad šizofrenija sergančiujų artimuosius ragina nebijoti kreiptis pagalbos i psichologus, nes tai gali padèti ir patiems geriau jaustis, ir pagerinti santykius su kitais šeimos nariais: ,...Paaiškinam, kad svarbu, kad ir šeimoj santykiai palaikantys būtu ir panašiai, nes lengviau visiems rüpintis tokia liga sergančiu žmogum, kai yra palaikymas...". Galima pažymèti, kad geri visų šeimos narių santykiai palengvina rūpinimąsi šizofrenija sergančiu artimuoju. Slaugytoja $S_{3}$ paaiškina, ,...kad labai svarbu prižiürèti ir save, rüpintis ir savo emocine būkle, nes kai šeimos nariai geriau jaučiasi, automatiškai šeimoje yra geresni tarpusavio santykiai tiek su sergančiu šizofrenija, tiek su kitais šeimos nariais...". Galima teigti, kad gera emocinè sveikata gerina šeimos tarpusavio santykius, todèl, pasak respondentės, labai svarbu išmokti skirti laiko sau ir pailsèti nuo nuolatinès artimojo priežiūros.

\section{Išvados}

1. Sergančiujų šizofrenija artimieji patiria neigiamą aplinkinių požiūrị ir vengimą, turi bendravimo problemų su sveikatos priežiūros specialistais ir sergančiuoju šeimos nariu.

2. Psichikos sveikatos slaugytojai konsultacijų sergančiųų šizofrenija artimiesiems metu dažniausiai rekomenduoja rūpintis savo emocine sveikata, stebèti, kad sergantis šeimos narys tinkamai vartotų paskirtus vaistus, moko bendrauti, pablogejus sergančiojo sveikatos būklei.

\section{Literatūra}

1. Kaakinen JR, Coehlo DP, Steele R, Tabacco A, Hanson SMH. Family health care nursing: theory, practice, and research (5th ed.). Philadelphia, PA: F. A. Davis 2015. ISBN 978-0-8036-3921-8.

2. Maiocco S, Shelley E, Salmond S, Jewell ST, Caldwell B, Lieggi M. Experiences of stigma among family members of persons living with schizophrenia: a systematic review protocol. JBI Database System Rev Implement Rep 2017;15(6):1575-1584. https://doi.org/10.11124/JBISRIR-2016-003150

3. World Health Organization. Schizophrenia. 2018. https://www. who.int/en/news-room/fact-sheets/detail/schizophrenia

4. Higienos institutas. Sergančių asmenų skaičius pagal diagnozių grupes. 2019. https://stat.hi.lt/default.aspx?report_id=237

5. Li R, Ma X, Wang G, Yang J, Wang C. Why sex differences in schizophrenia? J Transl Neurosci (Beijing) 2016;1(1):37-42.

6. National institute of mental health. Schizophrenia 2018.

https://www.nimh.nih.gov/health/statistics/schizophrenia.shtml

7. Allerby K, Sameby B, Brain C, Joas E, Quinlan P, Sjostrom N, Burns T, Waern M. Stigma and burden among relatives of persons with schizophrenia: results from the Swedish COAST study. Psychiatr Serv 2015;66(10):1020-1026.

https://doi.org/10.1176/appi.ps.201400405
8. Skubiejūtė G., Bukelskis L., Petružytė D. Šizofrenija sergančių artimujų santykių pokyčiai ir stigmatizacijos patirtis pirminiame socialiniame tinkle. Tiltai, 2017;77(2):73-88.

https://doi.org/10.15181/tbb.v77i2.1604

9. Koschorke M, Padmavati R, Kumar S, Cohen A, Weiss HA, Chatterjee S, Pereira J, Naik S, John S, Dabholkar H, Balaji M, Chavan A, Varghese M, Thara R, Patel V, Thornicroft G. Experiences of stigma and discrimination faced by family caregivers of people with schizophrenia in India. Soc Sci Med 2017;178:66-77.

https://doi.org/10.1016/j.socscimed.2017.01.061

10. Wright KM, Mckeown M. Essentials of mental health nursing. SAGE Publications (London). 2018. ISBN 978-1-5264-4716-6.

11. Yu Y, Liu Z, Tang B, Zhao M, Liu X, Xiao S. Reported family burden of schizophrenia patients in rural China. PloS One 2017;12(6):1-18.

https://doi.org/10.1371/journal.pone.0179425

12. Svettini A, Johnson B, Dip CM, Saunders J, Jones K, Silk S, Hargarter L, Schreiner A. Schizophrenia through the carers' eyes: results of a European cross-sectional survey. J Psych Mental Health Nurs 2015;22(7):472-483.

https://doi.org/10.1111/jpm.12209

13. Sabanciogullari S, Tel H. Information needs, care difficulties, and coping strategies in families of people with mental illness. Neurosci (Riyadh) 2015;20(2):145-152.

https://doi.org/10.17712/nsj.2015.2.20140713

\section{COLLABORATION BETWEEN A MENTAL HEALTH NURSE AND RELATIVES OF PATIENTS WITH SCHIZOPHRENIA: A QUALITATIVE STUDY}

\section{A. Grinkevičiūtė, A. Jakavonytė-Akstinienė}

Keywords: nurses, schizophrenia, relatives, collaboration.

Summary

More than 20 million people in the world suffer from schizophrenia. Many people diagnosed with schizophrenia live or maintain close ties with their family members, such as parents, brothers, sisters or children. The family members of patients with schizophrenia play a key role in the care of the sick, which makes many of them in situations where the aggression of the sick and self-harm occurs. The purpose of the study is to analyse the cooperation between the mental health nurse and relatives of patients with schizophrenia. The study involved 4 relatives of patients with schizophrenia and 4 mental health nurses. An interview method was used.

Conclusions. Relatives of patients with schizophrenia face negative attitude from the surrounding people and their evasion, problems in communicating with health professionals and difficulties in communicating. Mental health nurses to family members of patients with schizophrenia are usually recommended to take care of their emotional health, to monitor the proper use of the medicine used by schizophrenia. Mental health nurses also teach how to communicate with patient with schizophrenia when theirs health condition are worsens.

Correspondence to: a.jakavonyte-akstiniene@spf.viko.lt

Gauta 2020-07-07 